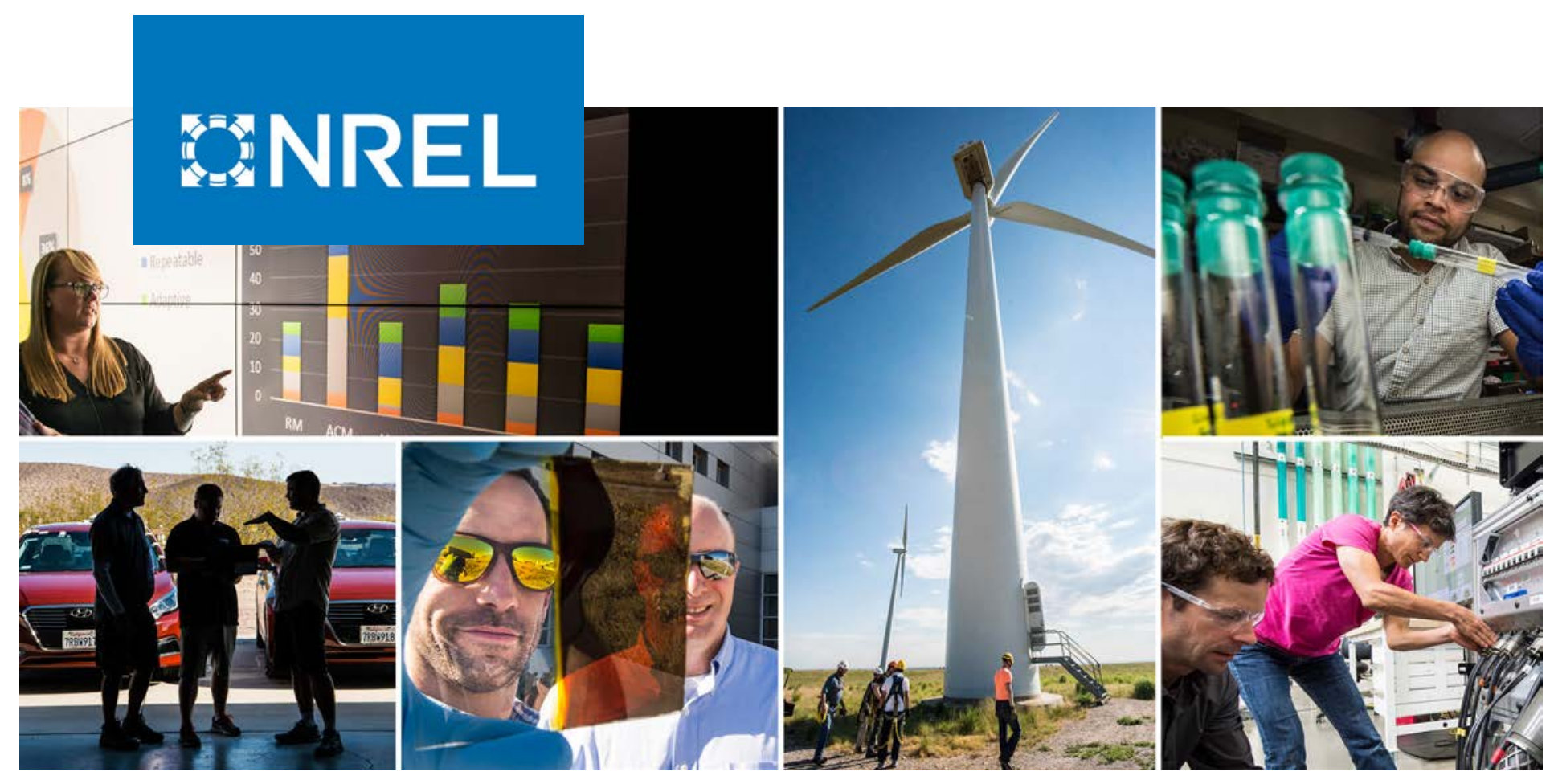

\title{
International Best Practices for Implementing and Designing Renewable Portfolio Standard (RPS) Policies
}

Jenny Heeter, ${ }^{1}$ Bethany Speer, ${ }^{1}$ and Mark B. Glick ${ }^{2}$

1 National Renewable Energy Laboratory

2 Hawaii Natural Energy Institute

NREL is a national laboratory of the U.S. Department of Energy

Office of Energy Efficiency \& Renewable Energy

Operated by the Alliance for Sustainable Energy, LLC

This report is available at no cost from the National Renewable Energy Laboratory (NREL) at www.nrel.gov/publications.

\section{Technical Report}

NREL/TP-6A20-72798

April 2019 


\section{GNREL}

\section{International Best Practices for Implementing and Designing Renewable Portfolio Standard (RPS) Policies}

Jenny Heeter, ${ }^{1}$ Bethany Speer, ${ }^{1}$ and Mark B. Glick ${ }^{2}$

1 National Renewable Energy Laboratory

2 Hawaii Natural Energy Institute

\section{Suggested Citation}

Jenny Heeter, Bethany Speer, and Mark B. Glick. International Best Practices for Renewable Portfolio Standard (RPS) Policies. 2019. Golden, CO: National Renewable Energy Laboratory. NREL/TP-6A20-72798. https://www.nrel.gov/docs/fy19osti72798.pdf.

NREL is a national laboratory of the U.S. Department of Energy Office of Energy Efficiency \& Renewable Energy Operated by the Alliance for Sustainable Energy, LLC

This report is available at no cost from the National Renewable Energy Laboratory (NREL) at www.nrel.gov/publications.

Contract No. DE-AC36-08GO28308
Technical Report NREL/TP-6A20-72798 April 2019

National Renewable Energy Laboratory 15013 Denver West Parkway Golden, CO 80401

303-275-3000 • www.nrel.gov 


\section{NOTICE}

This work was authored, in part, by the National Renewable Energy Laboratory, operated by Alliance for Sustainable Energy, LLC, for the U.S. Department of Energy (DOE) under Contract No. DE-AC36-08G028308. Funding provided by the United States Agency for International Development (USAID) under Contract No. IAG-17-2050.The views expressed in the article do not necessarily represent the views of the DOE or the U.S. Government including USAID.

This report is available at no cost from the National Renewable Energy Laboratory (NREL) at www.nrel.gov/publications.

U.S. Department of Energy (DOE) reports produced after 1991 and a growing number of pre-1991 documents are available free via www. OSTI.gov.

Cover Photos by Dennis Schroeder: (clockwise, left to right) NREL 51934, NREL 45897, NREL 42160, NREL 45891, NREL 48097, NREL 46526.

NREL prints on paper that contains recycled content. 


\begin{abstract}
ABOUT NREL
The National Renewable Energy Laboratory (NREL) is a national laboratory of the U.S. Department of Energy, Office of Energy Efficiency and Renewable Energy, operated by the Alliance for Sustainable Energy, LLC. With U.S. Government Support, NREL collaborates with the Vietnam Low Emission Energy Program to provide technical assistance to the Government of Vietnam in strengthening its enabling environment, including its power sector planning processes, for renewable energy development.
\end{abstract}

\begin{abstract}
ABOUT HNEI
The Hawaii Natural Energy Institute (HNEI), a research unit of the School of Ocean and Earth Science and Technology, University of Hawai'i at Manoa, conducts research of state, national and international importance to develop, test and evaluate novel renewable energy technologies. The Institute leverages its in-house work with public-private partnerships to demonstrate realworld operations and enable integration of emerging technologies into the energy mix. Founded in 1974, HNEI was established in statute in 2007 with an expanded mandate to coordinate with state and federal agencies. In this capacity, HNEI develops, deploys and demonstrates renewable energy systems and supports energy transitions, often through partnerships with industry and government, including state, national and international jurisdictions and organizations.
\end{abstract}

\title{
ACKNOWLEDGMENTS
}

For review of the paper, the authors thank Warren Leon, Clean Energy States Alliance; Ed Holt, Ed Holt and Associates; Dan Bilello, Sadie Cox, and Emily Newes, NREL; and Son Ha-Dang and Khanh Tuong Nguyen, Vietnam Low Emission Energy Program. For editorial support the authors thank Lauryn Dempsey and Mike Meshek (NREL). 


\section{Table of Contents}

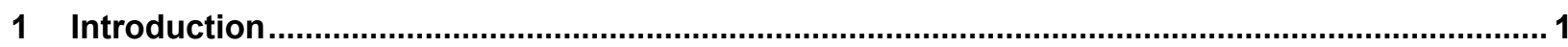

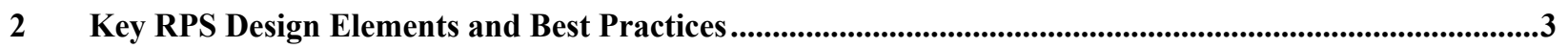

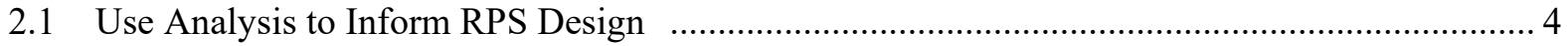

2.2 Gather Stakeholder Input in Developing Targets and RPS Design ......................................... 6

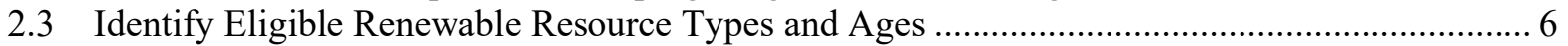

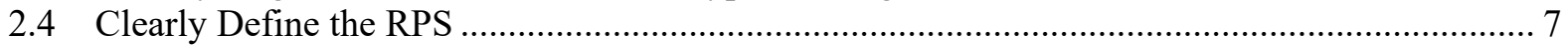

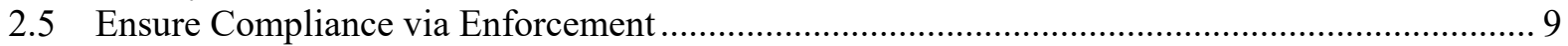

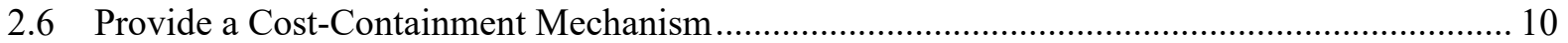

$3 \quad$ Policy and Procurement Mechanism Interactions ...............................................................................................12

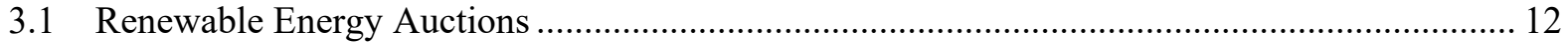

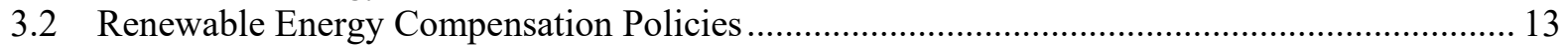

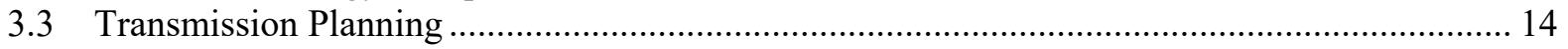

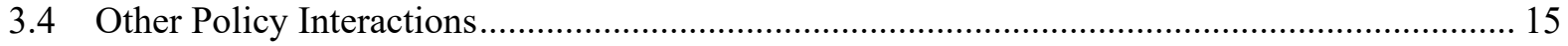

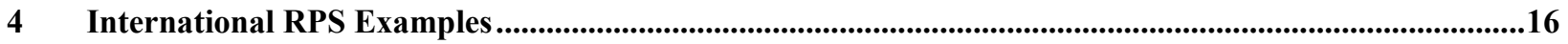

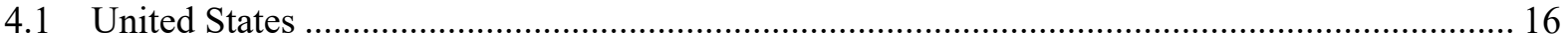

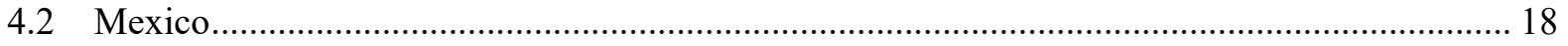

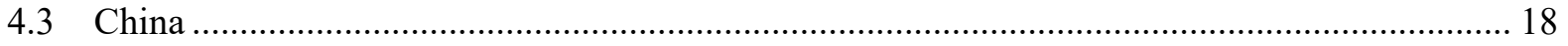

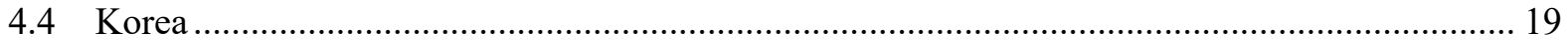

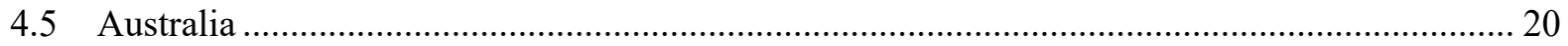

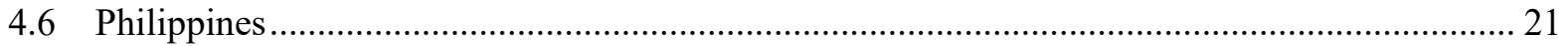

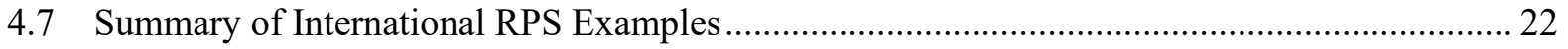

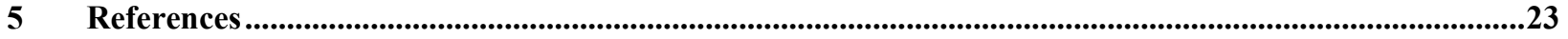




\section{List of Figures}

Figure 1. Distribution of RPS targets internationally, by terminal year date and

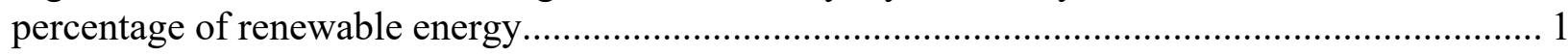

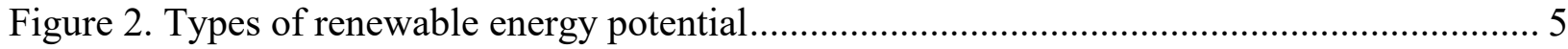

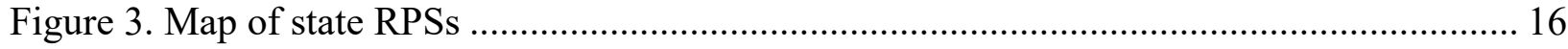

Figure 4. Growth in non-hydropower renewable generation from 2000 to $2016 \ldots \ldots \ldots \ldots \ldots \ldots \ldots . . . . . . . .17$

Figure 5. Annual and cumulative RPS capacity additions by technology ............................... 17

Figure 6. Progress toward the 2020 renewable energy target: January 2017-June 2018 ............ 21

\section{List of Tables}

Table 1. RPS Targets in Asia ............................................................................................. 2

Table 2. Examples of Key Components of an RPS …............................................................. 4

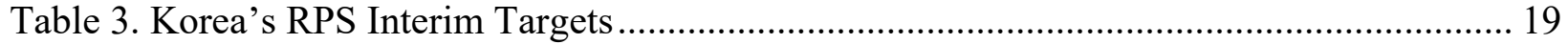

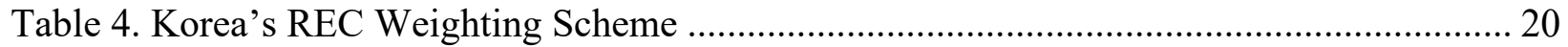

Table 5. Country-Specific Examples of How an RPS Can be Structured ................................. 22

\section{List of Text Boxes}

Text Box 1. Renewable Energy Certificate (REC) Tracking .................................................. 10 


\section{Introduction}

Renewable energy targets have been around since the 1970s and have taken several forms, including renewable energy action plans, government announcements, and renewable portfolio standards (IRENA 2015). In this report, we focus on one subset of renewable energy targets: renewable portfolio standards (RPSs). An RPS is a public policy tool requiring a certain amount of renewable electricity relative to the entire electricity supply. RPSs are an enforceable form of renewable energy targets (IRENA 2017); in order to be termed an RPS, there must be a compliance penalty for non-performance. As of April 2017, 173 countries had set some form of renewable energy target (IRENA 2017). Of those countries, at least 67 countries had set targets for renewable capacity or generation (IRENA 2017).

RPSs vary in their end or "terminal" year and percentage of renewable electricity required. Most countries have set RPSs at or below 30\%, with terminal dates of 2020 and 2030 being the most common (Figure 1)

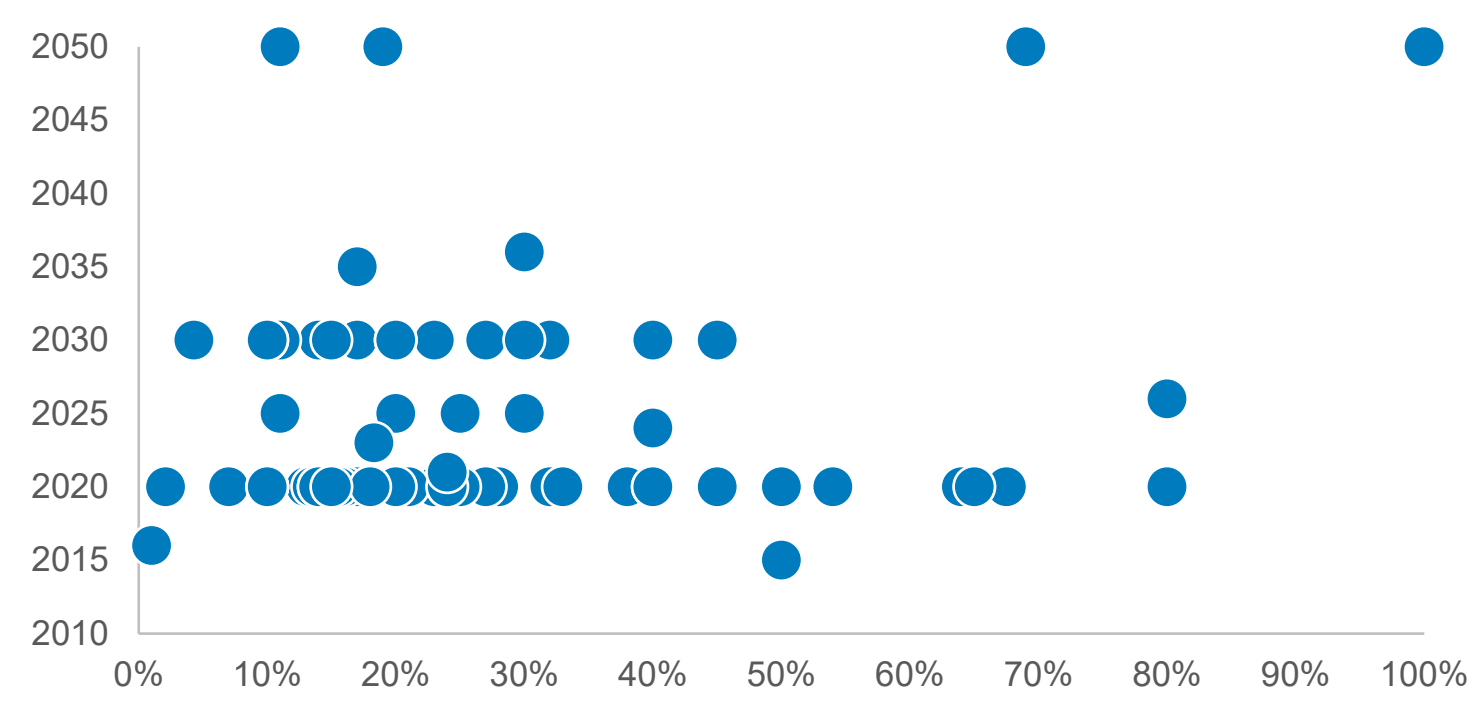

Figure 1. Distribution of RPS targets internationally, by terminal year date and percentage of renewable energy

Source: REN21 2017 
Within Asia, RPS targets vary from $10 \%$ to $30 \%$, with target years between 2020 and 2050 (Table 1).

Table 1. RPS Targets in Asia

\begin{tabular}{lll}
\hline Country & Target & Year \\
\hline Bangladesh & $10 \%$ & 2020 \\
\hline China & $20 \%$ & 2030 \\
\hline Indonesia & $25 \%$ & 2025 \\
\hline Republic of Korea & $11 \%$ & 2030 \\
\hline Lao People's Democratic Republic & $30 \%$ & 2025 \\
\hline Philippines (draft policy) & $35 \%$ & 2030 \\
\hline Vietnam & $20 \%$ & 2050 \\
\hline
\end{tabular}

Note: Thailand has a $30 \%$ target by 2036 as part of its Power Development Plan but the target is not an RPS.

Source: REN21 2017

RPS policies are all unique: different political motivations, target types, and technology approaches exist. For example, political jurisdictions may implement an RPS because of a desire for self-sufficiency, carbon emissions reductions/environmental protection, green jobs, economic development, improvement to the balance of trade, reduction in price volatility, or other reasons. These goals can serve as a starting point when considering the design of an RPS. An RPS can set a share of energy demand (e.g. 20\% of electricity supply) or fixed amount of energy production or consumption (in GW or GWh) (IRENA 2017). An RPS can also be technology-agnostic or specific, and it is typically a percentage of retail sales, which includes sales from conventional generation.

As RPSs expand globally, individual countries are working to incorporate them into their energy sector planning. In Vietnam, the government announced an updated plan for electricity development and renewable energy use. ${ }^{1}$ The plan calls for (1) increasing electricity supply (from $\sim 39,000$ megawatts (MW) in 2015 to $60,000 \mathrm{MW}$ in 2020 and 130,000 MW in 2030) and (2) increasing the share of electricity generated from renewable energy (from $6.5 \%$ in 2020 to $10.7 \%$ in 2030). The Prime Minister approved the country's Renewable Energy Development Strategy, which regulates the RPS for 2020, 2030, and 2050.

To ensure successful implementation of the RPS and other policies, the Government of Vietnam requested a policy study examining effective RPS policies globally. The key findings of that study, which were delivered to the Government of Vietnam, are described in this report, the purpose of which is to provide an overview of RPSs internationally and to highlight key design elements and best practices for RPSs. This report includes a discussion of the other polices that can support RPS fulfillment. It draws on case studies of policies in the United States, Mexico, China, Korea, Australia, and the Philippines.

\footnotetext{
${ }^{1}$ The Government of Vietnam announced this as part of the Revised National Power Development Plan VII (in short "the Revised PDP-7").
} 


\section{Key RPS Design Elements and Best Practices}

RPS policies vary internationally, but all are grounded in common elements generally designed to achieve the desired underlying policy objectives at the least cost. Common elements include a target, a target year, list of eligible renewable technologies, consideration of renewable imports, and a compliance and enforcement structure:

- RPS targets are typically set as a production target (in $M W h$ ). Setting a production target in megawatt-hours incentivizes project developers to use equipment and installations that maximize renewable energy generation. In some cases, targets have been set in megawatts (MW) (capacity). Though setting a capacity target may be less administratively complex, it does not consider how much electricity is actually produced. Thus, it could incentivize generators to come online but perhaps be located in areas with lower-quality resources (e.g., areas lacking steady winds) or in areas with high congestion, resulting in curtailment of renewable generation.

- RPS targets are typically established on an annual basis with an end-year target. For example, the RPS target may be $30 \%$ of annual retail electricity sales in 2030 , starting at $20 \%$ in 2020 and increasing $1 \%$ annually to reach the $30 \%$ end-year target. This provides certainty to project developers. All areas, but especially those with rapid load growth where end-year retail sales may be difficult to forecast, may need to develop mechanisms to determine the actual megawatt-hours required based on defined data sources (e.g. retail sales reports) and defined time frames (e.g. within one quarter after the calendar year ends).

- RPS policies provide a list of eligible technologies. Because stakeholders may have different definitions of "renewable," having a list of eligible technologies is essential for tracking compliance. In some cases, countries are establishing "clean" portfolio standards that include nuclear generation. In addition to which types of technologies are eligible, RPSs define any temporal constraints. For example, the RPS may include only renewable generation produced after the RPS was enacted.

- RPS policies determine whether renewable imports are eligible. The RPS can also be designed to either include or exclude renewable generation that is imported from a neighboring country or region, as (1) in some regions, significant amounts of electricity may already be imported, (2) renewable energy resources may be able to be developed at lower costs in other regions and then imported, and (3) legal, contract, or other restrictions may prohibit discriminating against electricity imports. In contrast, some RPS policies exclude renewable imports to support local industry and create jobs in-country, or for other reasons.

- A compliance and enforcement structure is essential to assure investors that a market for renewable technologies will exist over the life of their investment. An RPS is most impactful for mobilizing private sector investment if it is legally binding to reduce the likelihood of changes to the policy (IRENA 2017).

Examples of these common elements are provided in Table 2. 
Table 2. Examples of Key Components of an RPS

\begin{tabular}{ll}
\hline Key Component & Example \\
\hline Target & $20 \%$ renewable electricity by 2050 \\
\hline Interim schedule & $5 \%$ renewable electricity by $2020,10 \%$ by $2030,15 \%$ by 2040 \\
\hline Eligible resources & $\begin{array}{l}\text { All solar photovoltaics, wind, biomass, and hydropower facilities less than } 10 \\
\text { MW that began commercial operation on or after July } 1,2019\end{array}$ \\
\hline Compliance entities & All load-serving electricity companies with more than 50,000 customers \\
\hline Regulatory entity & Public Utilities Commission \\
\hline $\begin{array}{l}\text { Penalties for } \\
\text { noncompliance }\end{array}$ & $\$ 50 / M W h$ \\
\hline
\end{tabular}

In this section, we describe the key elements of RPS design along with RPS best practices, including (1) using analysis to inform RPS design, (2) gathering stakeholder input in developing targets, (3) identifying eligible renewable resource types and vintages, (4) clearly defining the RPS, (5) enforcing compliance, and (6) providing a cost-containment provision.

\subsection{Use Analysis to Inform RPS Design}

Ideally, analysis is done before the RPS is established; however, RPSs have sometimes been implemented quickly without much analysis. With better planning tools and economic data on renewables, setting the upper limits and interim targets of RPS policy can be informed by analysis of the technical and economic potential of renewable resources within the political jurisdiction. A fundamental question is the potential amount and value of renewable generating capacity. Renewable energy potential can be examined in multiple ways:

- Resource potential includes consideration of physical constraints, physical potential, and the energy content of the resource. For example, solar irradiance measures how much power per unit area is hitting the earth's surface (e.g., in units of $\mathrm{kWh} / \mathrm{m}^{2} /$ day) and is key to establishing solar capacity values. Measurements can also consider cloud cover, atmospheric water vapor and trace gasses, and other physical features that limit resource potential. The National Renewable Energy Laboratory (NREL), the World Bank, and others have developed resource potential maps and Geographic Information System (GIS) tools. See https://www.nrel.gov/international/global energy.html and https://maps.nrel.gov/rede-asean/ for more information.

- Technical potential further restricts resource potential to consider only areas where the resource could technically operate. These factors could include topographic constraints, land-use constraints, and system performance considerations. For example, solar PV modules cannot be installed on steep hillsides and may be restricted on federally protected land.

- Economic potential determines how much of the renewable resource is cost-competitive. For example, though there may be ample off-shore wind resource and technical potential, the costs may be too high, at least in the short term, to have much economic potential. 
The cost of any required infrastructure improvements, such as new transmission lines, can also be included when examining economic potential. Because economic potential will vary depending on technology costs, it is important to consider how these costs may change over time. To the extent that an RPS has multiple policy objectives (e.g., promoting the use of distributed generation, supporting new technologies), economic potential would be based on an assessment of how the additional objectives could be achieved as cost-effectively as possible for each of the resource options of the desired portfolio (Leon 2012).

- Market potential limits the renewable resources to those resource with economic potential that can be implemented in light of any existing policy, regulatory, or finance restrictions. For example, although a country might have large economic potential for large-scale hydropower facilities, other restrictions, such as the need to relocate impacted human populations, may in practice reduce the amount of large-scale hydropower developed.

The hierarchy of the different potential classifications and key assumptions within each are summarized in Figure 2. Understanding each level of potential (resource, technical, economic, and market) can help shape an effective RPS.

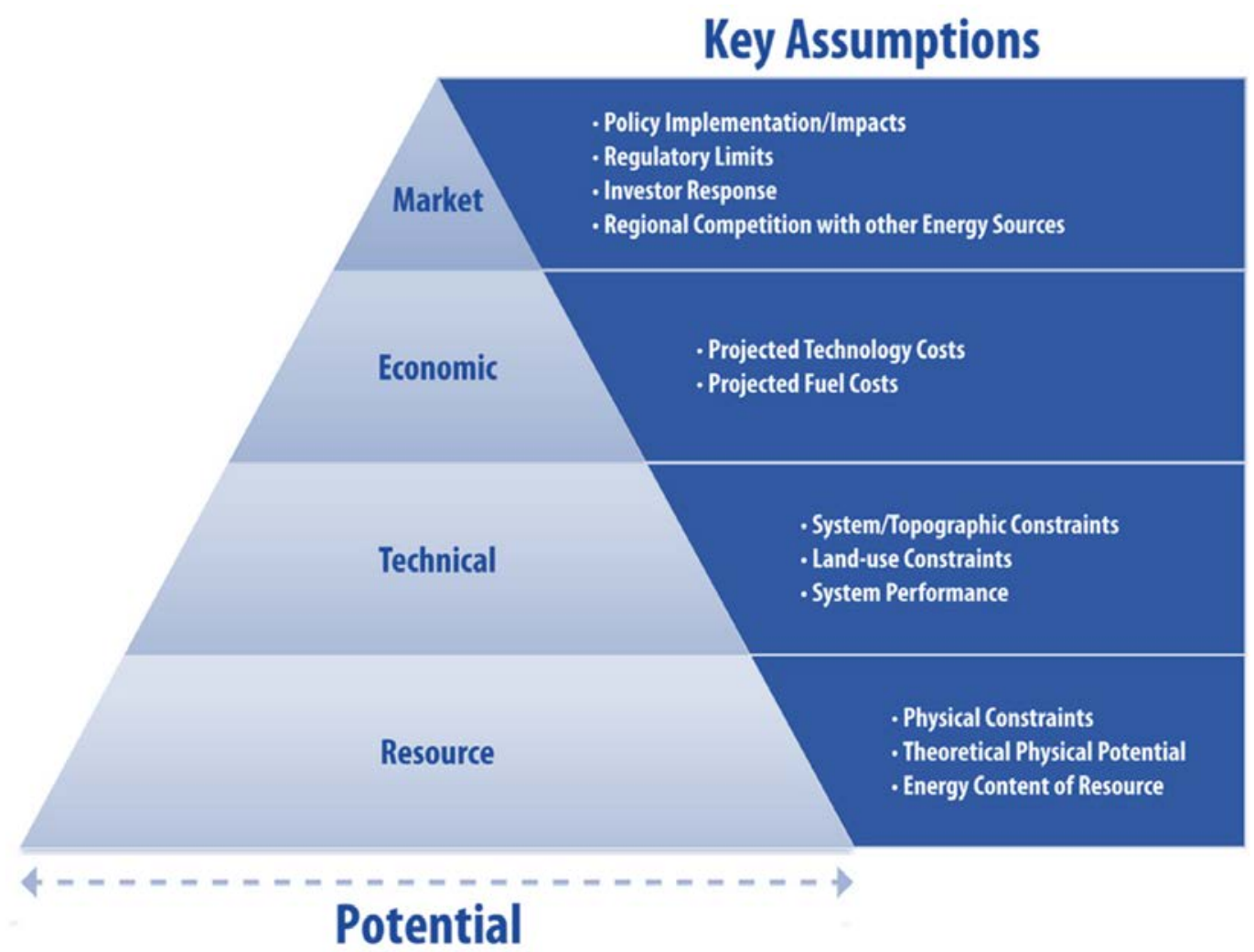

Figure 2. Types of renewable energy potential

Source: Lopez et al. 2012

When considering high rates of renewable penetration an understanding of electrical grid operational constraints based on load analysis and other modeling can be completed to ensure 
system reliability. ${ }^{2}$ Operational constraints will differ based on the types of renewable energy resources used, the percentage target, and other factors. Capacity expansion, production cost and optimization models, and scenario analysis can support an overall assessment of cost-effective, grid-connected renewable energy potential that can inform the selection of RPS targets.

\subsection{Gather Stakeholder Input in Developing Targets and RPS Design}

After analysis is completed, ultimate decisions will need to be made about the key elements to be specified in the RPS. Because RPS implementation is a long-term process that requires coordination and support among diverse parties, having stakeholder input and buy-in during the target development process can lead to smoother policy implementation and sustained support. If the process involves such things as legislation and rulemaking, the involvement of stakeholders in preparing the policy may prove critical to adoption of the policy.

For example, in Vietnam, a balanced working group of RPS stakeholders could be assembled to communicate with the Electricity and Renewable Energy Agency (EREA) about vetting the design. Such a working group may include any obligated entity (e.g., the utility), the energy regulator, the grid manager (e.g., the National Load Dispatch Center in Vietnam), renewable and non-renewable industry representatives, academia, representatives of consumer groups, as well as appropriate local, state, and federal policymakers. Because stakeholders come from diverse academic and professional backgrounds, working group members can be selected so that their experience and knowledge levels cover the technical review tasks and various aspects of the policy framework. For example, individuals with renewable resource siting and generating background and experience might gauge the technical feasibility, while community leaders, consumer advocates, and policymakers would anticipate and mitigate potential barriers that may need to be addressed to ensure implementation.

\subsection{Identify Eligible Renewable Resource Types and Ages}

Countries have defined eligible resources in different ways in order to meet their policy objectives. Policy objectives could include job creation, economic benefits, air quality benefits, or other objectives. Typically, RPSs define renewable resources to include solar, wind, geothermal, hydropower, and biomass. However, many countries restrict which renewable resources can be used based on costs, environmental impact, or other country objectives, for example, encouraging technologies that could better provide economic development or jobs benefits. Often, hydropower resources are limited to those with minimal environmental impact, for example, run-of-river hydropower. Hydropower projects may also be limited by the system size (e.g., $10 \mathrm{MW}$ ). Biomass resources may be restricted based on their carbon footprint, though that determination may be contentious, as different stakeholders may have different perspective on methods for examining carbon impacts.

Countries may consider providing mandates for individual technology types. In the United States, states commonly have a "carve-out" of their RPS policy for solar generation. Technology carve-outs can ensure the desired diversity of generating technologies; rather than a singular focus on the least cost option. Renewable energy diversity could be encouraged to limit overreliance on a single resource option, which could result in more intermittency than if

\footnotetext{
${ }^{2}$ See, for example, Energy Transition Initiative (2017) for details on Hawaii's distributed generation planning efforts.
} 
complementary resources are encouraged (e.g. if solar is peaking in midday and wind is peaking at night).

Countries may also want to consider limiting undesirable renewable energy projects. For example, if the country has a greenhouse gas reduction goal, it may want to restrict renewable energy projects that are built on forests or farmland, as cutting down trees and other vegetation would reduce the carbon reduction benefit of the renewable energy project. Countries may adopt complementary policies to address land use issues.

Finally, RPS polices may consider the age of qualifying renewable generators. For example, some countries may wish to include only generators that were installed after the RPS policy was established. Other RPS policies may establish a target that includes existing renewable resources and allows all existing and future renewable resources to qualify. Existing renewable energy projects may be fully paid for through preexisting contracts and may not require additional payments or contracts to be economically viable. The age of eligible generators can be an important consideration if the policy goal of the RPS is to drive new renewable energy generation. Countries may want to (1) consider setting a higher target and including existing renewable energy generators or (2) consider setting a lower target and excluding existing renewable generators. If the country does wish to include older renewable energy generators, it could create a separate tier for these generators so that they are not competing directly with new generators.

\subsection{Clearly Define the RPS}

Whether an RPS is established by statute, regulation or executive order, it is important that the authorizing language be clearly defined and unambiguous to avoid misinterpretation or misunderstanding by energy stakeholders and the public. Essential components that require clear definition include:

1. Allowable resource types

2. Timing of the interim and final targets

3. Specific entities to be held accountable for meeting targets and the method of compliance, reporting, and enforcement

4. Whether targets apply to all renewable generation — however defined — or only new generation

5. Exclusions or waivers, with attention to loopholes that might have unintended consequences.

\section{Obligated Entities}

Typically, RPSs are applied to entities that supply electricity to consumers. In a regulated electricity market, this would be the monopoly utility. In a restructured electricity market, it would be a retail electric supplier. Utilities and retail electric suppliers already procure electricity supply for their customers, and so may have the required capabilities and finance to procure renewable energy. In contrast, if an RPS obligation is placed on individual generating units, such as in Korea (see section 4.4) those units may not know how much renewable energy to procure, 
as they do not have information about retail sales. Generating units may also not have a contracting pathway to ensure the renewable energy is delivered to customers.

In some cases, large customers procuring their own electricity must also comply with RPS requirements. This is the case, for example, in Mexico. Large customers there may procure electricity via a power purchase agreement (PPA) with a renewable generator or via an electricity supplier that provides a specified percentage of renewable energy in its supply. For more on corporate procurement of renewable energy internationally, see Bird et al. (2017).

Policymakers can consider exemptions to the RPS when it may be reasonably expected to create an economic hardship to the electricity consumer or utility. RPS policies may consider the unknown cost of integrating renewable energy into the grid by providing exemptions for some utilities or customer types. For example, in the United States, some states have exempted small electricity suppliers (e.g., those that have less than a certain number of customers), particularly in remote locations, where renewable resources may be more difficult to develop or higher cost. Other entities may be exempt if the energy law or regulation does not or cannot apply to them.

\section{Determining the Target Timing}

Introducing an RPS may require some significant preparation time. The first compliance year may need to be years after the RPS law is passed. This will provide time for obligated entities to develop a compliance strategy, let some existing electricity contracts lapse, and allow time for new renewable energy projects to be built.

In order to support market development, RPSs also typically specify interim targets. Without this, compliance entities may under-procure renewable energy and be unable to meet a final target obligation. For example, if there is only one mandated target, $30 \%$ by 2030 , and no interim targets were established, such as $20 \%$ by 2020 , increasing one percentage point per year until 2030, compliance entities may reach 2030 and already have procured non-renewable resources to meet their load.

A final timing issue can exist when the RPS target is based on a percentage of retail sales. Because a year's final retail sales figures will be unavailable until after the year is concluded, compliance entities may need some time, for example, in the first quarter of the following year, to make sure their RPS purchases fulfill their obligation. This can be especially true in retail choice markets where a year's retail sales are more unpredictable than in a monopoly utility market. Rapid load growth may also lead to uncertainty about how much renewable energy will be required.

\section{Existing or New Contracts}

Policymakers should consider existing energy supply contracts when setting the final and interim targets of an RPS. Compliance entities may have existing power contracts or own non-renewable generation that has not recovered all its costs. To ensure the RPS can be met, compliance entities may be required to file an RPS compliance plan with their energy regulator. Such a plan would include details about how the compliance entity plans to transition from its existing power contracts and supply. 
Another option to address existing contracts is to make the RPS apply only to new contracts and renewable energy resources. Policymakers and regulators could work together to determine whether exempting existing contracts would still allow enough renewable generation to come online to meet the RPS.

\subsection{Ensure Compliance via Enforcement}

Oversight and enforcement are required for an RPS to be effective at deploying new renewable resources and meeting targets. Investors need to be confident a renewable energy market will exist over the life of the investment before making what in many cases are very large capital expenditures. Therefore, the methodology for assessing and verifying compliance needs to be clear, and it must ensure a designated oversight governmental body or authoritative entity that can enforce all penalties prescribed according to the RPS policy. Without these measures, critical investments may not be made due to lack of investor confidence and the RPS would function more as an aspiration rather than a firm, irrefutable objective on which renewable developers and investors could not rely.

Typically, compliance and enforcement are functions of the regulatory body that oversees electricity or energy. The RPS can set a schedule for the compliance entity to file reports (usually annually) to the regulatory body on its performance and progress toward interim targets. The reporting will depend on how the compliance entity procures renewable energy, its market structure, and other factors. For example, if the compliance entity is a monopoly utility that procures renewable energy vis-à-vis PPAs, an annual report might include both (1) an update on the amount of renewable energy produced during the year relative to the next interim target and (2) a copy of any contracts for renewable energy that were signed during the reporting year. Monopoly utilities may also own their renewable generation assets directly. In addition to providing contracting information, monopoly utilities would need to show some documentation via a meter reading or other measure, that the energy owned or contracted for was actually delivered. Another option to show compliance is to require compliance to be demonstrated with the use of renewable energy certificates (RECs), and defining a REC as the environmental attributes of one MWh from an eligible generator. Compliance entities could then show proof of RECs via a REC tracking system account. (See Text Box 1 for details on international tracking systems.)

\section{Enforcement}

If the regulatory body determines that the compliance entity has not met its obligations, a penalty or other means to address enforcement of the requirement can help ensure future annual targets will be met. Penalties established via law or regulation provide certainty that they will be enforced. One type of penalty is the alternative compliance payment (ACP). If the RPS requires a certain number of megawatt-hours of renewable electricity, an ACP might specify that the compliance entity must pay a penalty, such as $\$ 100$ for each MWh out of compliance. Regulators may find that a declining ACP schedule is appropriate, given anticipated declines in renewable energy costs. An ACP could start at a particular level and decline over time (e.g., starting at $\$ 100 / \mathrm{MWh}$ in the first year and declining by $\$ 10 / \mathrm{MWh}$ per year before plateauing at $\$ 50 / \mathrm{MWh}$ in all subsequent years). In the United States, ACPs have been structured so that they differ for solar carve-outs and the main tier of the RPS, in recognition that solar costs have historically been higher than costs of main tier resources (primarily wind). 
Other types of penalties could be used for noncompliance. For example, in California, there is not an ACP, but regulators are allowed to assess fees on the utility for noncompliance. The fees cannot be passed on to ratepayers but instead must be absorbed by the utility's shareholders.

\section{Text Box 1. Renewable Energy Certificate (REC) Tracking}

Around the globe, there are systems to track RECs, which may also be termed "energy attribute certificates", "green energy certificates" or other terms. While some operate in multiple countries, others are country-specific. Tracking systems are electronic registries and as such, require software and database expertise to develop. Typically, a third-party with expertise in software and database development will develop and maintain the tracking system. The government may fund the third-party directly or have it funded via participant fees. In the United States, most tracking systems have a governance board that sets and revises operations protocols. Governments and other users of the tracking system participate in the governance. Tracking systems that cover multiple regions include:

- International REC (I-REC) Standard: This standard was developed by a nonprofit organization as a framework for standardization across REC tracking systems. It supports issuing, tracking and redeeming RECs in 24 countries as of February 2019. It provides a central tracking platform that local tracking systems may use.

- $\quad$ Tradable Instruments for Global Renewables (TIGRs): Developed by environmental registry service provider APX, TIGRs are energy attribute certificates hosted on a tracking platform and with certain standards for eligible generation types. TIGRs are predominantly used in Southeast Asia (e.g., Singapore and Philippines).

Country-specific REC tracking systems include the following:

1. Australia's Large-scale Generation Certificates (LGCs) and small-scale technology certificates (STCs): In Australia, the government supports a REC registry that tracks and allows for the transfer of LGCs and STCs. LGCs are used to demonstrate compliance with the country's renewable energy target. They have broad resource eligibility and are produced by over 500 generators and target wholesale markets with minimum parcel sizes of 5,000 certificates.

2. Mexico's Certificados de Energía Limpia (CELs): These certificates were established for compliance with national clean energy requirements for corporate and industrial customers. CELs have broad resource eligibility, including nuclear and cogeneration in addition to renewable generation, though the formula for calculating CEL generation favors renewables and distributed generation.

3. South Africa's zaRECS: The zaRECs market has 29 registered generators and is based on the European Energy Certificate System.

4. United States' RECs: REC markets were established for compliance with state-level RPSs and voluntary markets.

Source: IRENA (2018)

\subsection{Provide a Cost-Containment Mechanism}

Given uncertainty in future generation costs, most RPSs have a cost containment mechanism. This mechanism ensures customers are protected from excessive cost increases associated with the policy by lawfully exempting the obligated entity from complying with the RPS during that reporting period.

Common ways to cap costs include: 
- Alternative Compliance Payment (ACP): As discussed in the previous section, an ACP places a ceiling on the cost of compliance as entities are allowed to pay the ACP in lieu of contracting for renewable generation. This makes the ACP effectively a cap on the cost of compliance because obligated entities will not pay more for RECs than the ACP.

- Cost Cap: Retail rate caps are designed to ensure end-use consumer electricity rates do not rise above a specified percentage or dollar amount. Rate caps are typically structured to examine the incremental costs of the RPS compared to the cost of retail electricity service. Obligated entities are exempt from RPS procurement to the extent that incremental costs exceed the retail rate cap. Retail rate caps can be challenging to calculate, as the rates are based on "incremental RPS costs;" those costs need to be calculated based on what the compliance entity would have done absent an RPS policy (Heeter et al. 2014). For example, the cost of renewable procurement would be compared to the projected cost of the resource the compliance entity would have used without the RPS mandate. Because that purchase did not actually occur, the cost has to be estimated. 


\section{Policy and Procurement Mechanism Interactions}

Setting an RPS target is only one step in supporting renewable energy deployment. It may be desirable to also develop policies and procurement strategies that enable financing of new renewable energy projects. Renewable energy developers need a clear, often long-term method to be compensated for the electricity produced. As of early 2015, at least 60 countries were addressing the need for long-term financing by using renewable energy auctions to procure renewable energy (IRENA and CEM 2015). Some countries have mandates for renewable energy auctions that can work either separately from or in conjunction with an RPS. In other countries, feed-in-tariffs, bilateral contracting, and/or competitive solicitations are used for RPS procurement (Kreycik, Couture, and Cory 2011). These renewable procurement options are also used in countries without an RPS. This section highlights policies and procurement mechanisms that can assist in RPS implementation.

\subsection{Renewable Energy Auctions}

Renewable energy auctions are one way to provide long-term contracts for renewable energy that can then be used to meet an RPS. Without long-term contracts, the revenue a project will receive via energy sales is uncertain. Long-term contracting is important so that project developers can provide the revenue certainty needed to secure project financing. Renewable energy auctions can be structured in multiple ways. Internationally, it is common for a utility or government to issue a solicitation for a certain amount of capacity or generation. Project developers then submit their price bids, and bids are selected based on cost and possibly other criteria (IRENA and CEM 2015). Auctions may include a component that screens developer qualifications before allowing them to bid. After that, bidders are allowed to submit sealed-bids; selection is done based on price alone. In this way, auctions allow for both price competition and greater price transparency and discovery than other procurement avenues.

Key considerations for auctions include:

- Ensure a Sufficiently Large Marketplace: Without a significant pool of bidders, pricing will not be competitive. Factors that impact market size include the timing of the auction as well as the amount of renewable energy being purchased (Kreycik, Couture, and Cory 2011).

- Mitigate Against Project Failure: If bidders bid at too low a price, they may not have the funds needed to build their projects. To ensure against project failure, the auction could require that winning bidders be penalized for noncompliance. Winning bidders could be required to post a construction bond to ensure funds are available to assess noncompliance.

- Lower Transaction Costs by Streamlining Procurement: Developing a bid may be timeconsuming, especially for new project developers. This has the effect of limiting the market to more experienced developers, which could result in less price competition. Reverse auctions create a streamlined process that may minimize costs to bidders (Cox et al. 2015). 


\subsection{Distributed Renewable Energy Generation Compensation Policies}

Generation from on-site distributed generation is typically allowed in an RPS. A method for compensating these distributed generation systems for their electricity output is needed, as they will not be selling directly to a wholesale market or utility. Common compensation policies include policies such as a feed-in-tariff (FIT) and net metering. ${ }^{3}$

FITs provide administratively set prices for renewable energy compensation (e.g., 10 cents per kilowatt-hour) under a long-term, fixed-price contract. Renewable developers see benefits from a FIT because their long-term revenue is relatively fixed, allowing them to gain access to financing. From an administrative and economic perspective, setting and adjusting FIT pricing can be challenging, particularly with declining renewables costs. That means that once the tariff is set, it could provide less or more compensation than developers need to finance their projects.

According to Cox and Esterly (2016), key components of FIT design — some of which address some of the previously mentioned challenges - include:

- Setting and Revising FIT Payment Levels: FIT payments can be set based on the technology type and market status. Policymakers may want to decrease the FIT payments as renewable energy costs decline.

- Providing a Cost Containment Approach: This can be done by limiting either the capacity of projects that will be eligible for the FIT or the total funding available through the FIT program.

- Establishing long-term contracts and guaranteeing grid access.

Net metering policies provide another method for compensating distributed renewable energy generation. Customers receive either a monetary or a kilowatt-hour reduction in their monthly bill for generation consumed, while the excess is exported to the grid.

Key components of net metering design include:

- Determining the Compensation Rate: In the United States, net metering compensation is usually set at the retail rate, though other methodologies exist. Some utilities compensate distributed generation at a time-of-use rate, which can be favorable to solar if the solar peak coincides with the peak time-of-use rate. Utilities and policymakers may also want to consider how their rates may incentivize the use of storage paired with distributed generation. For example, net metering policies that provide low compensation rates for sending energy back to the grid at certain times may have the effect of incentivizing distributed generation paired with storage.

- Providing a Cost Containment Approach: Similar to FIT design, net metering policies can cap the amount of generation allowed under the program (i.e., implementing a "program cap") and/or the size of individual generators allowed (Heeter et al. 2014).

- Treatment of Excess Generation: When a customer generates more electricity than is used, net metering policies can determine whether the generation is rolled over to the next month, the next year, or indefinitely. Some policies proscribe that excess generation

\footnotetext{
${ }^{3}$ FITs can also be used to compensate utility-scale generators.
} 
at the end of the year be compensated rather than continually rolled over to the next period. $^{4}$

For example, compensation policies played a key role in developing distributed energy in Hawaii. Early-stage renewable energy growth there was primarily driven by customer participation in net metering and standard interconnection agreement programs. Together, these programs accounted for more than $90 \%$ of the distributed energy resources capacity installed in the Hawaiian Electric Company service territories. The feed-in tariff program accounted for the remainder. These programs were established to encourage customers to install distributed energy resources with standardized agreements and simpler compensation mechanisms. The net metering program was successful in creating a local market for distributed energy resources, spurring such rapid growth that the 2015 interim RPS target of $15 \%$ was exceeded by $8.4 \%$ (Energy Transition Initiative 2017).

\subsection{Transmission Planning}

Depending on the aggressiveness of the RPS and other factors, countries may want to consider expanded transmission capacity. In particular, if renewable energy resources are far from where energy demand is located, new transmission may be required (Cochran et al. 2012). Without adequate transmission capacity to transport renewable energy to where it is needed, that renewable energy may not be delivered. As a result, the RPS targets may not be met.

For example, transmission planning and stakeholder engagement efforts were successful in enabling new transmission projects in Texas through its "competitive renewable energy zone" (CREZ) process. Senate Bill 20 directed the state's public utilities commission to develop a CREZ process, ultimately leading to the development of transmission projects to transmit more than 18,000 MW of wind from the western part of the state to the eastern part.

According to Cochran et al. (2012) and Lee, Flores-Espino and Hurlbut (2017), key components of a renewable energy zone process include:

- Delegating Planning Authority to One Centralized Institution: The goal here is to ensure one institution has planning authority to streamline the planning process. This lead organization can oversee planning and be responsible for its completion. Separate working groups can be established to identify appropriate zones and modeling transmission expansion options.

- Allowing Public Input into Transmission Siting: Even when one institution leads the planning process, engaging stakeholders throughout the process is still important. Engaging the public can provide input into which locations might be available for transmission development.

- Aligning Planning of Timescales for Generation and Transmission Development: Renewable energy projects can be developed in a few years, while constructing new transmission typically takes 10 or more years, from start to finish. As a result, renewable energy projects may be developed but be constrained by existing transmission capacity. By speeding up transmission development, renewable energy projects and transmission capacity timing can be aligned.

\footnotetext{
4 “Net Metering,” NREL, https://www.nrel.gov/state-local-tribal/basics-net-metering.html.
} 
In cases where transmission build out may be too costly or otherwise unfeasible, jurisdictions may want to evaluate the benefits of off-grid or micro-grid solutions.

\subsection{Other Policy Interactions}

Countries may have complementary polices that interact with an RPS, including:

- Tax Incentives: Providing tax incentives, such as the federal production tax credit in the United States, to renewable energy projects improves the economic viability of renewable energy projects. The tax code can also be used to provide property tax or other tax exemptions for renewable energy projects.

- Financial Incentives: These can include upfront payments for renewable energy deployment, ongoing payments, or credit mechanisms such as loan programs, guarantees, and credit enhancements (Cox 2016).

- Carbon Reduction Policies: Cap-and-trade or carbon tax policies can effectively raise the price of carbon-emitting generation, thereby making the price of renewable energy more cost-competitive.

- Energy Efficiency Mandates: Where an RPS is based on a percentage of retail sales, if the amount of retail sales declines, the amount of renewable energy required would decline accordingly. Setting an energy efficiency portfolio standard or target can be a desirable strategy for areas with significant projected energy growth. 


\section{International RPS Examples}

The RPS case studies described in this section provide examples of the various ways RPSs can be structured, given local power markets and government priorities. We review policies in the United States, Mexico, China, Korea, and Australia to provide examples of policy structures. We also discuss the draft RPS design in the Philippines in this section. Policy examples are summarized in Table 5.

\subsection{United States}

The United States has both vertically integrated and restructured power markets, providing a variety of policy examples. Policy structures vary in terms of targets, time frames, obligated entities, technologies, vintages, locations, resource tiers/carveouts/multipliers, ${ }^{5}$ REC mechanisms, contracting requirements, compliance mechanism, cost caps, and other features (Barbose 2017).

In the United States, RPSs have been implemented at the state level since the 1980s. They are enacted in 29 states and the District of Columbia (Figure 3), and they apply to 56\% of total U.S. retail electricity sales (Barbose 2017).

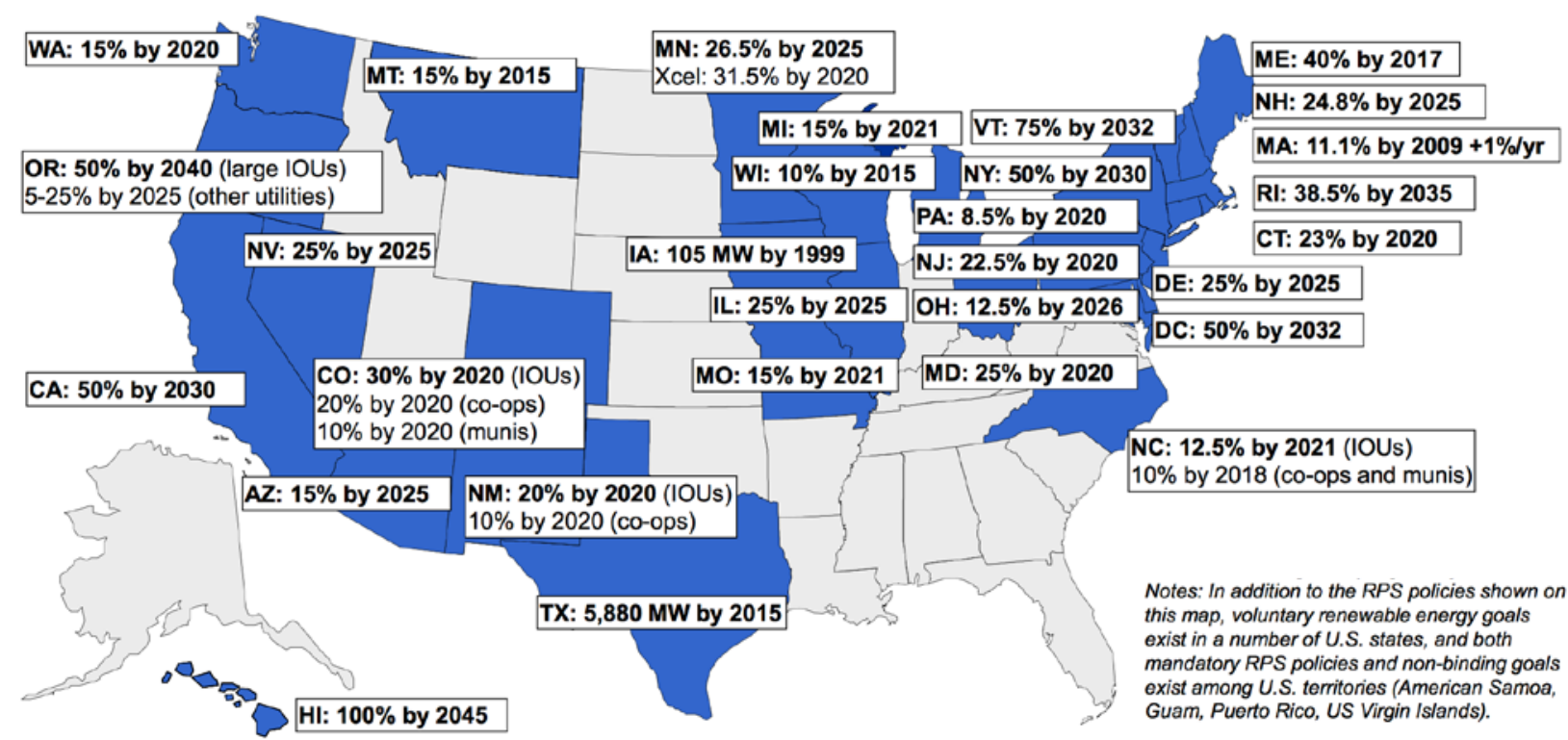

Figure 3. Map of state RPSs

Source: Barbose 2017

$\mathrm{IOU}=$ investor-owned utility

Since RPSs were initially adopted, policy details have evolved significantly. One key change has been increased end-year targets, with states such as Hawaii (75\% by 2040 and $100 \%$ by 2045), Vermont ( $75 \%$ by 2032), California ( $50 \%$ by 2030 ), and Oregon ( $50 \%$ by 2040 ) pursuing

\footnotetext{
${ }^{5}$ Resource tiers or carveouts refers to a set percentage of the RPS that is dedicated to a particular resource type or class of renewable energy (e.g. solar or distributed generation). Multipliers are incentives (e.g. 2x credit) for particular resource types or classes.
} 
the highest penetration levels. About 18 states have established solar or distributed generation carveouts.

RPSs have contributed to approximately $50 \%$ of total U.S. renewable energy generation growth for renewable energy since 2000 (Barbose 2017). Total renewable energy growth actually exceeded RPS requirements owing to voluntary corporate procurement and green power markets, utility purchases of renewable energy based on economic decisions, and RPS requirements being exceeded by obligated entities (Figure 4). Although historically wind was the primary resource making up RPS requirements, today solar is contributing the most on a capacity basis, due to solar carve-outs and the economic competitiveness of utility-scale solar in some markets (Figure $5)$.

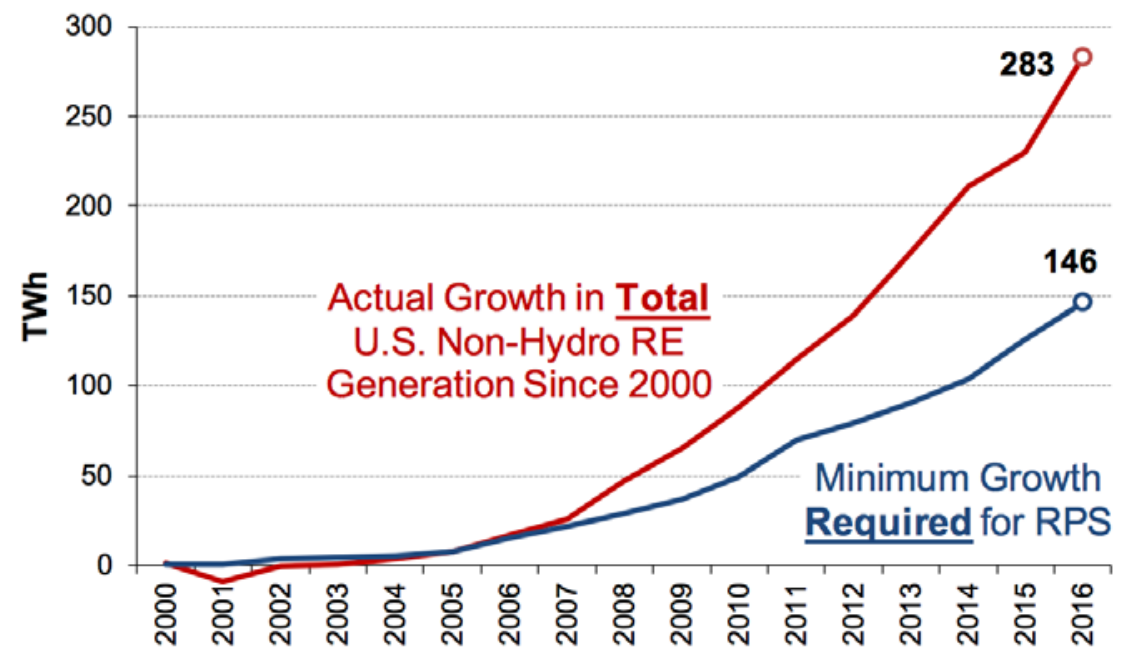

Figure 4. Growth in non-hydropower renewable generation from 2000 to 2016

Source: Barbose 2017 TWh = terawatt-hours

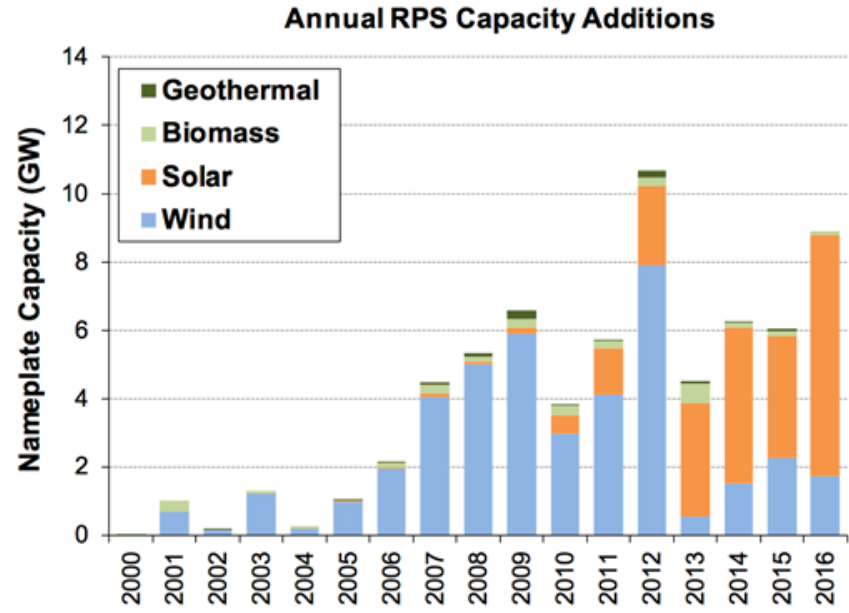

Cumulative RPS Capacity Additions

Notes: "RPS Capacity Additions" represent RE capacity contracted to entities subject to an RPS or sold on a merchant basis into regional RPS markets. On an energy (as opposed to capacity) basis, wind represents approximately $75 \%$, solar $16 \%$, biomass $5 \%$, and geothermal $4 \%$ of RPS-related renewable energy growth.

Figure 5. Annual and cumulative RPS capacity additions by technology

Source: Barbose 2017 


\subsection{Mexico}

In 2012, Mexico passed the General Climate Change Law with clean energy generation targets (Export.gov 2017). Then, beginning in 2013, Mexico began to undertake extensive constitutional power sector reforms including separating generation and distribution and creating a wholesale power market controlled by an independent grid operator. As part of those reforms, Mexico established new clean energy targets for electricity generation: $25 \%$ by $2018,30 \%$ by 2021 , and $35 \%$ by 2024 (Zinaman et al. 2018).

Compliance entities include load-serving entities and large consumers that purchase energy from the wholesale market. To comply, obligated entities must purchase clean energy certificates (or CELs - certificados de energías limpias in Spanish) which are akin to RECs and represent one megawatt-hour of power generated without fossil fuels (IEA 2017). CELs can be purchased separately from electricity through the wholesale market or together with electricity as part of long-term PPAs, including via renewable energy auctions. The penalty for noncompliance is $\$ 200$ per certificate. Oversight is provided by the Comisión Reguladora de Energía (the Commission on Energy Regulation, or CRE) (Zinaman et al. 2018). As of June 2017, Mexico was well on its way to meeting its clean energy standard with renewable energy representing $20.82 \%$ of total electricity generation (Rodrigues 2017).

\subsection{China}

In 2016, China's National Energy Administration adopted the $13^{\text {th }}$ Renewable Energy Development Five Year Plan, for 2016-2020. This plan established renewable energy targets through 2020. The targets were to increase non-fossil energy to $15 \%$ by 2020 and $20 \%$ by 2030 (IEA 2018). And in 2018, the National Energy Administration released a draft national policytitled Renewable Portfolio Standard and Assessment Methods (NEA 2018) — that proposes key changes to the renewable mandate, including the following:

1. Regulated Entities: Include provincial grid companies, distribution companies and retail electricity companies, industrial users with captive power plants, and commercial and industrial users who purchase power bilaterally.

2. Mandatory RPS with a Penalty System: State power grids will determine a replacement REC price, and entities can buy replacement RECs to make up any shortcoming in their obligation. If the mandate is not met, the government can delay approval of new fossil fuel capacity, or it can reduce the approved capacity. For retail electricity companies that do not comply, their market trading power can be reduced or canceled in the following year.

3. Shift from Capacity Targets to Generation Targets: The draft obligation is based on a percentage of the megawatt-hours of renewable production compared to total electricity sales. This is a shift from China's earlier megawatt targets, which resulted in capacity installations that suffered high levels of curtailment, in some cases (Hove and Wetzel 2018).

The draft policy also provides non-hydropower renewable energy power targets for 2020, by province, along with 2018 targets (NEA 2018). According to the draft policy, all market entities 
in the same province have the same target. The 2018 targets average $9.4 \%$ and the 2020 targets average 12.2\% (Hove and Wetzel 2018).

\subsection{Korea}

Korea's RPS was implemented beginning in 2012, and it has since been revised. The RPS requires generation companies (gencos) with over $500 \mathrm{MW}$ of capacity to procure a minimum of $10 \%$ of "new" and renewable energy by 2023 . While the compliance entity is set at the genco level, the Korea Electric Power Corporation (KEPCO) has monopoly rights on transmission, distribution, and retail sales and a near monopoly on generation.

The RPS includes annual interim targets (Table 3). The obligated entities can either produce renewable energy or procure the power and RECs through the Korean Power Exchange, which is the required forum for nearly all gencos to sell power, excluding those in island communities (KEPCO 2018; Lee, Kim and Kim 2018). Penalties for noncompliance are a maximum of 150\% of trading prices of RECs. The penalty varies depending on the cause and frequency of noncompliance.

Table 3. Korea's RPS Interim Targets

\begin{tabular}{|l|l|l|l|l|l|l|l|l|l|l|l|l|}
\hline Year & $\mathbf{2 0 1 2}$ & $\mathbf{2 0 1 3}$ & $\mathbf{2 0 1 4}$ & $\mathbf{2 0 1 5}$ & $\mathbf{2 0 1 6}$ & $\mathbf{2 0 1 7}$ & $\mathbf{2 0 1 8}$ & $\mathbf{2 0 1 9}$ & $\mathbf{2 0 2 0}$ & $\mathbf{2 0 2 1}$ & $\mathbf{2 0 2 2}$ & $\mathbf{2 0 2 3}$ \\
\hline $\begin{array}{l}\text { Ratio } \\
(\%)\end{array}$ & 2.0 & 2.5 & 3.0 & 3.0 & 3.5 & 4.0 & 5.0 & 6.0 & 7.0 & 8.0 & 9.0 & 10.0 \\
\hline
\end{tabular}

Source: KEPCO 2018

Examples of "new" energy include hydrogen, fuel cells, liquified coal, and other technologies. The Korean definition of renewable energy includes solar, wind, water, marine, geothermal, biomass, waste-to-energy, and other technologies. Rather than using carveouts, Korea is using a weighted REC scheme ${ }^{6}$ to incent investments in certain technologies and applications. For example, floating solar PV, fuel cells, tidal waves, and energy storage connected to wind power receive greater REC weights. See Table 4 for details on the weighting scheme.

Renewable energy suppliers smaller than $1 \mathrm{MW}$ can opt to sell power to the Korea Electric Power Corporation (KEPCO) via a PPA. Larger suppliers can use the Korean Power Exchange to trade both power and RECs, with electricity prices being determined by the system marginal price. Suppliers need to register their projects and apply to the Korea Energy Agency's New and Renewable Energy Center (KEMCO) to certify RECs within 90 days of the power being generated. KEMCO issues RECs to qualifying suppliers within 30 days. However, given the fluctuation in electricity prices, a recent change enabled renewable energy suppliers over $1 \mathrm{MW}$ to also bundle the sale of power and RECs via fixed price, 20-year contracts. This was done to reduce the risk to renewable energy suppliers by providing stable revenue over the economic life of a project.

\footnotetext{
${ }^{6}$ Also referred to as a "multiplier" in the United States. Multipliers have been less common that the use of set-asides or carve-outs for individual technologies in the United States (Wiser, Barbose, and Holt 2010).
} 
Table 4. Korea's REC Weighting Scheme

\begin{tabular}{|c|c|c|c|}
\hline \multirow[t]{2}{*}{ Category } & \multirow{2}{*}{$\begin{array}{l}\text { REC } \\
\text { Weighting }\end{array}$} & \multicolumn{2}{|l|}{ Energy Source and Criteria } \\
\hline & & Facility Type & Criteria \\
\hline \multirow[t]{6}{*}{ Solar PV } & 1.2 & \multirow[t]{3}{*}{ Facility installed on general site } & Less than $100 \mathrm{~kW}$ \\
\hline & 1.0 & & More than $100 \mathrm{~kW}$ \\
\hline & 0.7 & & More than $3,000 \mathrm{~kW}$ \\
\hline & 1.5 & \multirow[t]{2}{*}{ Facility installed on existing buildings } & Less than $3,000 \mathrm{~kW}$ \\
\hline & 1.0 & & More than $3,000 \mathrm{~kW}$ \\
\hline & 1.5 & \multicolumn{2}{|l|}{ Facilities floating on the water } \\
\hline \multirow[t]{10}{*}{ Others } & 0.25 & \multicolumn{2}{|c|}{ Integrated gas combined cycle, byproduct gas } \\
\hline & 0.5 & \multicolumn{2}{|l|}{ Waste, landfill gas } \\
\hline & 1.0 & \multicolumn{2}{|c|}{$\begin{array}{l}\text { Hydro, onshore wind, bioenergy, refuse derived fuel, waste } \\
\text { gasification, and tidal power (with embankment) }\end{array}$} \\
\hline & 1.5 & \multicolumn{2}{|c|}{$\begin{array}{l}\text { Wood biomass } \\
\text { Offshore wind (grid connection of less than } 5 \mathrm{~km} \text { ) }\end{array}$} \\
\hline & 2.0 & \multicolumn{2}{|l|}{ Fuel cell, tidal power } \\
\hline & 2.0 & \multicolumn{2}{|c|}{$\begin{array}{l}\text { Offshore wind (grid connection of more than } 5 \mathrm{~km} \text { ), geothermal, tidal } \\
\text { power (without embankment) }\end{array}$} \\
\hline & $1.0-2.5$ & \multirow{4}{*}{$\begin{array}{l}\text { Energy storage systems (connected to } \\
\text { wind power) }\end{array}$} & Origination Year \\
\hline & 5.5 & & 2015 \\
\hline & 5.0 & & 2016 \\
\hline & 4.5 & & 2017 \\
\hline
\end{tabular}

Source: KEPCO Research Institute 2018

\subsection{Australia}

In Australia, RPSs have been used at the federal and state levels. At the federal level, the Renewable Energy Target (RET) went into effect in 2011. It requires compliance entities to supply $16 \%$ renewable energy, which increases to $23.5 \%$ in 2020 (Clean Energy Regulator 2018a; IEA 2017a). Compliance entities are usually electricity retailers, which are defined as any "individual or company who is the first person to acquire electricity on a grid which has an installed capacity of 100 MW or more" (Clean Energy Regulator 2018a).

The RET includes one target for generation from large-scale generators and one from small-scale generators. Targets use RECs to determine compliance based on the size of the generator, termed large-scale generation certificates (LGCs) and small-scale technology certificates (STCs). Compliance entities must retire a certain number of LGCs and STCs (IEA 2017a). LGCs are issued for every megawatt-hour of large-scale renewable energy. STCs are issued to small-scale generators upfront for estimated generation through 2030; the upfront issuance allows STC developers (e.g., homeowners) to fund their purchases. 
If compliance is not met, a non-deductible shortfall charge must be paid, though $10 \%$ of a shortfall can be carried forward to the following year with no penalty. Penalties are AUD 65 for each REC (IEA 2017a).

The policy does allow for exemptions by businesses involved with Emissions-Intensive TradeExposed, or EITE, activities (Clean Energy Regulator 2018b). EITE industries are those with high emissions that are price sensitive to international markets, for example, aluminum smelting.

The Clean Energy Regulator, which tracks progress toward the 2020 target, estimates that 6,400 MW of projects would be needed to meet the target. As of June 2018, there were 8,309 MW of projects: 2,290 MW were in operation, 5,275 MW were committed, and 744 MW were probable (Clean Energy Regulator 2018c). See Figure 6.

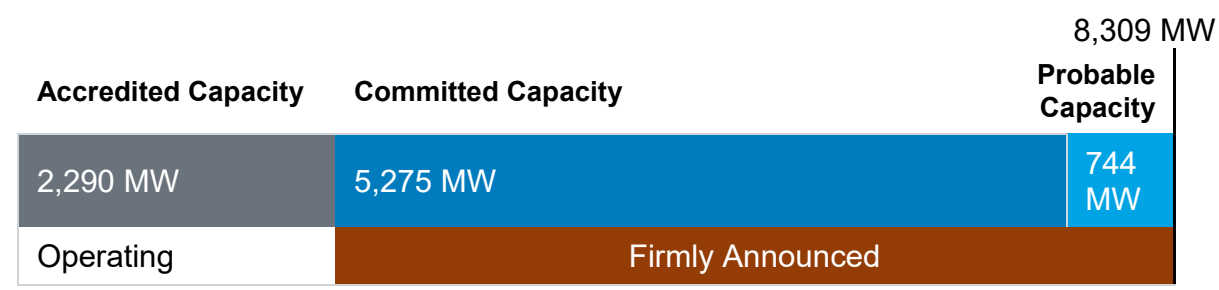

Figure 6. Progress toward the 2020 renewable energy target: January 2017-June 2018

Source: Clean Energy Regulator 2018c

\subsection{Philippines}

While Philippines does not currently have an RPS, it has completed a draft design of an RPS. Until recently, the Philippines had driven renewable energy development largely through a FIT that provided a kilowatt-hour payment to qualified renewable energy generators. However, the policy required interconnection to the grid before a project could be considered eligible, thus putting considerable risk on the project developer. The tariff level was also aggressive, resulting in a program that was ultimately oversubscribed and that left many projects stranded.

Given the political and cost challenges associated with a FIT, the Philippines government decided to move toward an RPS - the first in Southeast Asia. The RPS, currently in draft form, sets a $35 \%$ by 2030 target and requires distribution utilities, electric cooperatives, and retail electricity suppliers to source a portion of their energy supply from eligible renewable energy facilities. Eligible technologies include biomass, waste-to-energy, wind energy, solar energy, run-of-river hydropower, impounded hydroelectric power systems, ocean energy, hybrid systems, and geothermal. Eligible projects are issued RECs and can sell them to compliance entities. Compliance entities may also source renewable energy from PPAs or from their own generators.

The current target is set at $1 \%$ annual increments. However, this is estimated to only achieve a $23 \%$ penetration by 2030 and may not result in the building of renewable energy capacity beyond business-as-usual projections. Annual increments may need to be raised if the $35 \%$ by 2030 target is to be reached (Duffy and Janubas 2018). 


\subsection{Summary of International RPS Examples}

Countries have set different RPS target levels and end years (Table 5). They provide examples of how energy attributes have been used for demonstrating RPS compliance. They also highlight how compliance penalties have been set, and which entities are required to comply with the RPS.

Table 5. Country-Specific Examples of How an RPS Can be Structured

\begin{tabular}{|c|c|c|c|c|}
\hline $\begin{array}{l}\text { Country } \\
\text { (or State) }\end{array}$ & $\begin{array}{l}\text { RPS Target } \\
\text { (End Year) }\end{array}$ & $\begin{array}{l}\text { Energy Attribute } \\
\text { Mechanism }\end{array}$ & $\begin{array}{l}\text { Compliance } \\
\text { Entities }\end{array}$ & $\begin{array}{l}\text { Compliance } \\
\text { Penalty }\end{array}$ \\
\hline $\begin{array}{l}\text { California } \\
\text { (United } \\
\text { States) }\end{array}$ & $50 \%(2030)$ & $\begin{array}{l}\text { renewable energy } \\
\text { certificate (REC) }\end{array}$ & $\begin{array}{l}\text { utilities (some smaller } \\
\text { utilities are exempt) }\end{array}$ & $\begin{array}{l}\text { administrative } \\
\text { penalties at the } \\
\text { discretion of the } \\
\text { regulator }\end{array}$ \\
\hline Mexico & $35 \%(2024)$ & $\begin{array}{l}\text { clean energy } \\
\text { certificate (CELs) }\end{array}$ & $\begin{array}{l}\text { load-serving entities } \\
\text { and large consumers } \\
\text { that purchase energy } \\
\text { from the wholesale } \\
\text { market }\end{array}$ & $\begin{array}{l}\text { administrative } \\
\text { penalties of } \\
\$ 200 / \mathrm{MWh}\end{array}$ \\
\hline $\begin{array}{l}\text { China } \\
\text { (draft policy) }\end{array}$ & $20 \%(2030)$ & in development & $\begin{array}{l}\text { provincial grid } \\
\text { companies, } \\
\text { distribution } \\
\text { companies and retail } \\
\text { electricity companies, } \\
\text { industrial users with } \\
\text { captive power plants, } \\
\text { and commercial and } \\
\text { industrial users who } \\
\text { purchase power } \\
\text { bilaterally }\end{array}$ & $\begin{array}{l}\text { requirement to buy } \\
\text { replacement RECs; } \\
\text { penalties can include } \\
\text { delay or cancellation } \\
\text { of fossil fuel capacity } \\
\text { or reduced market } \\
\text { trading power }\end{array}$ \\
\hline Korea & $11 \%(2030)$ & $\begin{array}{l}\text { RECs self-generated } \\
\text { or purchased }\end{array}$ & $\begin{array}{l}\text { generation companies } \\
\text { with over } 500 \mathrm{MW} \text { of } \\
\text { capacity }\end{array}$ & $\begin{array}{l}\text { maximum of } 150 \% \text { of } \\
\text { REC trading prices } \\
\text { are imposed for } \\
\text { noncompliance; } \\
\text { amount of penalties } \\
\text { depends on causes } \\
\text { and frequency of } \\
\text { noncompliance }\end{array}$ \\
\hline Australia & $\begin{array}{l}23.5 \% \\
(2020)\end{array}$ & $\begin{array}{l}\text { RECs; up to } 10 \% \text { of } \\
\text { non-compliance may } \\
\text { be forgiven in year } \\
\text { one if the shortfall is } \\
\text { made up in the } \\
\text { following year }\end{array}$ & electricity retailers & AUD 65 per REC \\
\hline
\end{tabular}




\section{References}

BNEF (Bloomberg New Energy Finance). 2018. Global Corporate Database.

Barbose, Galen. 2017. U.S. Renewables Portfolio Standards: 2017 Annual Status Report. Berkeley, CA: Lawrence Berkeley National Laboratory. http://etapublications.lbl.gov/sites/default/files/2017-annual-rps-summary-report.pdf.

Lori Bird, Jenny Heeter, Eric O'Shaughnessy, Bethany Speer, Christina Volpi, Orrin Cook, et al. 2017. Policies for Enabling Corporate Sourcing of Renewable Energy Internationally: A 21st Century Power Partnership Report. Golden, CO: National Renewable Energy Laboratory. NREL/TP-6A50-68149. https://www.nrel.gov/docs/fy17osti/68149.pdf.

Clean Energy Regulator. 2018a. "The Renewable Power Percentage.” Australian Government Clean Energy Regulator. March 29, 2018.

http://www.cleanenergyregulator.gov.au/RET/Scheme-participants-and-industry/the-renewablepower-percentage.

_. 2018b. "Renewable Energy Target: Industry Assistance." Australian Government Clean Energy Regulator. August 3, 2018. http://www.cleanenergyregulator.gov.au/RET/Schemeparticipants-and-industry/Industry-assistance.

_.2018c. "Large-Scale Renewable Energy Target Market Data." Australian Government Clean Energy Regulator. July 18, 2018.

http://www.cleanenergyregulator.gov.au/RET/About-the-Renewable-Energy-Target/Large-scaleRenewable-Energy-Target-market-data\#progress.

Cochran, Jaquelin, Lori Bird, Jenny Heeter, and Douglas J. Arent. 2012. Integrating Variable Renewable Energy in Electric Power Markets: Best Practices from International Experience, Summary for Policymakers. National Renewable Energy Laboratory. NREL/TP-6A00-53730. https://www.nrel.gov/docs/fy12osti/53730.pdf

Sadie Cox. 2016. Financial Incentives to Enable Clean Energy Deployment: Policy Overview and Good Practices. Golden, CO: National Renewable Energy Laboratory. NREL/TP-6A2065541. https://www.nrel.gov/docs/fy16osti/65541.pdf.

Cox, Sadie, and Sean Esterly. 2016. Feed-in Tariffs: Good Practices and Design Considerations. National Renewable Energy Laboratory. Clean Energy Ministerial. NREL/TP-6A20-65503. https://www.nrel.gov/docs/fy16osti/65503.pdf

Cox, Sadie, and Sean Esterly. 2016. Renewable Electricity Standards: Good Practices and Design Considerations. National Renewable Energy Laboratory. Clean Energy Regulators Initiative. NREL/TP-6A20-65507. https://www.nrel.gov/docs/fy16osti/65507.pdf

Sadie Cox, Terri Walters, Sean Esterly, and Sarah Booth. 2015. Solar Power: Policy Overview and Good Practices. Golden, CO: National Renewable Energy Laboratory. NREL/TP-6A2064178. https://www.nrel.gov/docs/fy15osti/64178.pdf. 
Duffy, Alastair, and Rhesa Janubas. 2018. "Insight: Renewable Portfolio Standards to Come to the Philippines: Will They Be Effective at Driving a New RE Future?" Poyry. July 11, 2018. http://www.poyry.com/news/articles/insight-renewable-portfolio-standards-come-philippineswill-they-be-effective-driving.

Energy Transition Initiative. 2017. Integrated Distribution Planning Helps Hawaii Chart the Course for Ongoing Growth in Distributed Generation. Playbook Lesson Learned: Phase 6: Process Improvement. U.S. Department of Energy. https://www.eere.energy.gov/islandsplaybook/pdfs/phase6-hawaii-distribution.pdf

Export.gov. "Mexico Renewable Energy." U.S. Department of Commerce and Trade. Last updated October 12, 2018. https://www.export.gov/article?id=Mexico-Renewable-Energy.

Heeter, J., G. Barbose, L. Bird, S. Weaver, F. Flores-Espino, K. Kuskova-Burns, and R. Wiser. 2014. Survey of State-Level Cost and Benefit Estimates of Renewable Portfolio Standards. Berkeley, CA: Lawrence Berkeley National Laboratory. LBNL-6589E. Golden, CO: National Renewable Energy Laboratory. NREL/TP-6A20-61042. https://www.nrel.gov/docs/fy14osti/61042.pdf.

Heeter, J., R. Gelman, and L. Bird. 2014. Status of Net Metering: Assessing the Potential to Reach Program Caps. Golden, CO: National Renewable Energy Laboratory. NREL/TP-6A2061858. https://www.nrel.gov/docs/fy14osti/61858.pdf.

Henze, Veronika. 2018. "Tumbling Costs for Wind, Solar, Batteries Are Squeezing Fossil Fuels" Bloomberg New Energy Finance. March 28, 2018. https://about.bnef.com/blog/tumbling-costswind-solar-batteries-squeezing-fossil-fuels/\# ftnref1

Hove, Anders, and Daniel Wetzel. 2018. "China is Planning Provincial Quotas for Clean Energy.” Chinadialougue. April 23, 2018. https://www.chinadialogue.net/blog/10574-China-isplanning-provincial-quotas-for-clean-energy-/en

IEA (International Energy Agency). 2018. "IEA/IRENA Joint Policies and Measures Database: China 13th Renewable Energy Development Five Year Plan (2016-2020).” International Energy Agency. https://www.iea.org/policiesandmeasures/pams/china/name-161254-en.php.

_ 2017a. Policies and Measures: Australia: Renewable Energy Target. International Energy Agency.https://www.iea.org/policiesandmeasures/pams/australia/name-22211-en.php.

- 2017b. Status of Power System Transformation. International Energy Agency. https://www.iea.org/publications/freepublications/publication/StatusofPowerSystemTransformati on2017.pdf.

IRENA (International Renewable Energy Agency). 2018. Corporate Sourcing of Renewables: Market and Industry Trends - REmade Index 2018. International Renewable Energy Agency, Abu Dhabi. 
- 2017. Renewable Energy Target Setting and Support Schemes: Regional Workshop on Renewable Energy in Central Asia. April 26, 2017. International Renewable Energy Agency. https://www.irena.org/-/media/Files/IRENA/Agency/Events/2017/Apr/26/7-Session-IIRenewable-Energy-Target-Setting-and-Support-Schemes-Diala-Hawila.pdf

—. 2015. Renewable Energy Target Setting. International Renewable Energy Agency. http://www.irena.org/documentdownloads/publications/irena re target setting_2015.pdf.

IRENA and CEM (Clean Energy Ministerial). 2015. Renewable Energy Auctions: A Guide to Design. International Renewable Energy Agency. https://www.irena.org//media/Files/IRENA/Agency/Publication/2015/Jun/IRENA_Renewable Energy_Auctions_A_G uide to Design 2015.pdf.

KEPCO Research Institute. 2018. Personal communications with KEPCO Research Institute.

Kreycik, Claire E., Toby D. Couture, and Karlynn S. Cory. 2011. Procurement Options for New Renewable Electricity Supply. Golden, CO: National Renewable Energy Laboratory. NREL/TP6A20-52983. https://www.nrel.gov/docs/fy12osti/52983.pdf.

Lee, Hoon, Kim, Hera, and Pan-Soo Kim. 2018. "Renewable Energy: Korea." Getting the Deal Through. September 2018. https://gettingthedealthrough.com/area/99/jurisdiction/35/renewableenergy-korea/.

Lee, Nathan, Francisco Flores-Espino, and David Hurlbut. 2017. Renewable Energy Zones (REZ) Transmission Planning Process: A Guidebook for Practitioners. Golden, CO: National Renewable Energy Laboratory. NREL/TP-7A40-69043.

https://www.nrel.gov/docs/fy17osti/69043.pdf.

Leon, Warren. 2012. Designing the Right RPS: A Guide for Selecting Goals and Program Options for a Renewable Portfolio Standard. State-Federal Collaborative and the National Association of Utility Commissioners (NARUC). https://www.cesa.org/assets/2012Files/RPS/CESA-RPS-Goals-and-Program-Design-Report-March-2012.pd .

Lopez, Anthony, Billy Roberts, Donna Heimiller, Nate Blair, and Gian Porro. 2012. U.S. Renewable Energy Technical Potentials: A GIS-Based Analysis. Golden, CO: National Renewable Energy Laboratory. NREL/TP-6A20-51946.

https://www.nrel.gov/docs/fy12osti/51946.pdf.

NEA (National Energy Administration). 2018. "National Energy Administration Comprehensive Division on the Solicitation of Renewable Energy Power Quotas and Comments on the Assessment Method: Draft for Comments." March 23, 2018. National Energy Administration. http://zfxxgk.nea.gov.cn/auto87/201803/t20180323 3131.htm.

NREL (National Renewable Energy Laboratory). "Feed-in Tariffs." National Renewable Energy Laboratory. https://www.nrel.gov/state-local-tribal/clean-energy-strategies.html.

__. "Net Metering." National Renewable Energy Laboratory. https://www.nrel.gov/statelocal-tribal/clean-energy-strategies.html. 
REN21 (Renewable Energy Policy Network for the 21st Century). 2017. Renewables Global Status Report. http://www.ren21.net/gsr-2018/.

Rodríguez, Jessica. 2017. "Reporte de Avances de Energías Limpias, Al Primer Semestre de 2017." SENER. Presentation for the "Consejo Consultivo para la Transición Energética." December 11, 2017.

Wiser, Ryan, Galen Barbose, and Edward Holt. 2010. Supporting Solar Power in Renewables Portfolio Standards: Experience from the United States. Berkeley, CA: Lawrence Berkeley National Laboratory. LBNL-3984E. https://eetd.lbl.gov/sites/all/files/publications/report-lbnl3984e.pdf.

Zinaman, Owen, Alexandra Aznar, Francisco Flores-Espino, and Alejandro Tovar Garza. 2018. The Status and Outlook of Distributed Generation Public Policy in Mexico. Golden, CO: National Renewable Energy Laboratory. NREL/TP-6A50-71469.

https://www.nrel.gov/docs/fy18osti/71469.pdf. 